\title{
Feasibility of Android-Based iSpring Suite Learning Media in Fiqh Subjects
}

\author{
*Indah Miftahul Umam ${ }^{1}$, Siti Sulaikho \\ ${ }^{1,2}$ Universitas KH. Abdul Wahab Hasbullah, Tambakberas, Indonesia \\ *indahmiftahulu@gmail.com
}

\begin{abstract}
This research aims to know the properness of iSpring Suite based android system in Fiqh Material for The first grade in MTSN 14 Megaluh, Jombang. This research using Design-Based Research in Brog and Gall Approach. The research Instrument is formed as questionnaire validation of Material expert, linguistic expert, IT expert. On the other hand, there is also questionnaire validation for students respons. The assessment is conducted by classroom mean Score, Likert Scale. The result from a material expert is $81,91 \%$ which claim as extremely proper, from the linguistic expert is $80,25 \%$ which named by very good. Besides, the score from IT experts is 70,61\% which state as an appropriate category. And the score from the students is around 90\%, Which state is highly proper. In conclusion, Ispring suite Learning Media based Android System in Fiqh Material is Proper to use.
\end{abstract}

Penelitian ini bertujuan untuk mengetahui kelayakan sistem android berbasis iSpring Suite pada Materi Fiqih Kelas I di MTSN 14 Megaluh, Jombang. Penelitian ini menggunakan Design Based Research dengan Pendekatan Brog and Gall. Instrumen penelitian berupa angket validasi ahli materi, ahli bahasa, ahli IT, selain itu juga terdapat validasi angket untuk respon siswa. Penilaian dilakukan dengan skor rata-rata kelas, Skala Likert. Hasil dari ahli materi sebesar $81,91 \%$ yang menyatakan sangat tepat, dari ahli bahasa sebesar $80,25 \%$ yang disebut dengan sangat tepat. Selain itu, skor dari pakar IT adalah 70,61\% yang masuk dalam kategori layak. Dan nilai dari siswa sekitar $90 \%$, yang menyatakan sangat tepat. Kesimpulannya, Media Pembelajaran Ispring suite berbasis Sistem Android dalam Materi Fiqih Layak untuk digunakan.

Keywords: Learning Media, Android, Ispring Suite, Fiqh.

Received: April 21, 2021; Revised: May 27, 2021; Accepted: June 28, 2021

\section{INTRODUCTION}

In the era of the industrial revolution 4.0, the development of digital technology is very rapid and developing in all lines of life. This is marked by the proliferation of operating systems that facilitate human performance and mobility. On the other hand, this is also a demand for all elements of life in developing their respective technologies. No exception in the education aspect, technology seems to be excellent in facilitating and assisting the teaching and learning process, which is still synonymous with the lecture method and the teacher's tendency to dominate the 
learning process in the classroom. In addition, the discussion method is used as a way to discuss one subject topic (Amarulloh, R., 2013).

In this era of globalization, the acceleration of the development of learning media in education has also experienced a very significant quality improvement. In practice, information technology has become a demand in developing learning media (Muhson, 2010).

The word media comes from Latin, which is the word medium, which means an intermediary or introduction (zainati, 2017). Print media emerged after the invention of the printer by Johan Gutenberg Drs. It is a human, material, or event that builds conditions that enable students to acquire knowledge, skills or attitudes. This sense includes teachers, books, texts, and the environment as a medium (Arsyad, 2020). This becomes very beneficial because the availability of learning media will open up vast learning opportunities not only for students (Zukhrufin, Anwar, \& Sidiq, 2021). But over time, technological developments also demand human creativity in conducting or creating a solid operating system. This is because flexible and also multifunctional. This is what is offered by Android, where Android is an operating system on Linuxbased mobile devices. In addition, Android allows developers to create creative applications that they want themselves (Kuswanto, J. \& Radiansyah, 2018).

Android is a service that helps developers send data from the server for their android applications to android devices (Juwansyah, 2015). This allows developers to be more creative in creating more quality learning media. Meanwhile, in designing applications as learning media, a platform is needed to focus on design patterns by the learning process rules. In this case, the iSpring Suite can convert presentation files into flash files (Himah, 2017). Therefore, iSpring Suite is a platform that is very suitable for use in the process of developing learning media based on Android. On the other hand, Microsoft Corporation is the presentation application program that is most widely used today (Sukiman, 2012).

iSpring Suite is one of the integrated tools with Microsoft PowerPoint (Sasahan, Oktova, \& I.R.N., 2017). The iSpring Suite was also created to make it easier for educational activists to develop exciting learning media. This will significantly support the effectiveness of learning and can improve student achievement (Martiningsih, 2018). In addition, the integration between Microsoft PowerPoint and the iSpring Suite 8 software will produce engaging learning media (Evi Damayanti, 2018).

Therefore, teaching and learning achievement result from continuous talent development efforts (Eva \& Siagian, 2012). To clarify the direction of this research, the formulation of the problem raised is how material experts, linguists and media experts assess the iSpring Suite.

\section{METHOD}

In this research process, researchers use research and development methods or also known as R\&D. In Saputro's research, Sugiono explained that research and development methods are research methods used to produce a particular product, then test the effectiveness of the product. In the development of this $\mathrm{R} \& \mathrm{D}$, there are several research models (Saputro, 2017) (Izzati \& Sumarsih, 2017). 
The Android-based learning media development model using the iSpring Suite adapts to the development model. This model consists of 4 stages of development, namely define, design, develop and disseminate. This research includes research that produces products to test the effectiveness of a product. Researchers carried out the development stages of research on developing android-based learning media using the iSpring Suite to improve student achievement (Hidayati \& Hakim, 2012).

The first stage is the definition to determine and define the learning requirements. This stage is carried out by conducting an analysis stage on the principal, students, and teachers of fiqh subjects at MTSN 14 Megaluh. The second stage is designed by designing learning devices. This step becomes the link that connects the definition and design stages. In this stage, the selection of media suitable for delivering the subject matter is also carried out. In addition, at this stage, the choice of the format is carried out. Format selection is made by reviewing the existing device formats and has been developed in developed countries.

The third stage is the development stage to produce revised learning tools based on expert input. Validation of the device by experts is followed by revision and then simulation, namely activities to operationalize learning plans. This activity is carried out for the implementation of time matching devices and tool functions. The fourth stage is deployment, which is the stage of using devices developed on a broader scale (Huda, Sakti, \& Ary, 2019). The product resulting from this research is software or software (Sutiasih \& Saputri, 2019).

The research data was collected using a material expert validation sheet, a linguist and then analyzed using a Likert scale. In this study, researchers are more likely to use a pattern of proving the validity of which conclusions are drawn from the validation results. For example, the validation of fiqh learning media using the iSpring Suite on Friday prayer material was studied by three experts, consisting of material experts, linguists, and media experts. After being validated by all experts, the researcher made improvements.

\section{RESULT AND DISCUSSION}

\section{Fiqh in Islamic Education}

Religious education is currently faced with the challenges of modernity which are increasingly complicated and massive. Education is also a conscious and planned effort for a learning atmosphere and learning process to develop their potential to have religious-spiritual strength actively. There is an impression that the practice and procedure of Islamic education are sterile from the context of reality, which is an acute problem that occurs in almost all of the Islamic world. The worldly problem is a manifestation of a dichotomous perspective on science, where there is religious knowledge on one side and general knowledge. Islamic religious education in formal institutions prioritizes the nuances of fiqiyah, which is oriented to right and wrong, reward-sin, likewise in teaching. According to Jalaluddin Rahmat, three characteristics show fiqh as a diniyah paradigm: first, a single truth. At first, fiqh departed from one's understanding of the texts, namely the Qur'an and hadith (Ikhwan, Anwar, \& Mahmudah, 2021). Then the companions and scholars of the salaf tried to understand and draw conclusions from both. 
Furthermore, the latest scholars analyze, process information from these friends and scholars, and produce fatwas that are by the conditions and situations of the times. Scond, it is an absolute and divine sources, so there is no debate between the two. Third, righteousness is measured by loyalty to fiqh. In this position, the level of diversity of people is measured by whether or not they are treated well (Hanafi, 2017).

In learning fiqh teachers are one of the success factors, teachers need to know and mean to carry out their duties besides teachers. Several reasons can affect the learning process, and students' psychological conditions can also affect learning achievement. So from there, a teacher needs to continue to understand students in the learning process. Teachers need to understand the essential characteristics of students and student growth (Mansir. F \& Karim. A, 2020).

In fiqh subjects, especially in the Friday prayer chapter itself, several problems are encountered in learning and practice. Friday prayer is a prayer that must be performed on Friday. The time is the same as the midday prayer. The total number of raka'at is two raka'at. Before completing the prayer, the priest gives a sermon to the congregation as much as two sermons.

In this research, there are steps taken to improve learning media design products through Microsoft Powerpoint iSpring Suite. These stages include considering the quality of the design and the suitability of the display with the psychological development of students, adjusting the content of the material with references so that the material packaged in the learning media becomes effective and easy to understand. In addition, there are also improvements added by the validator, which in its assessment provides suggestions to replace the column with an icon display. Meanwhile, linguists and material experts suggest adjusting the writing of the correct standard language and not mixing the writing styles of other languages.

The result of defining in the process of learning fiqh is through observations made by researchers. The design stage results (design) were obtained through interviews with fiqh subject teachers, school principals, and students and conducted at MTSN 14 Megaluh Jombang. Interviews with teachers of fiqh subjects showed the unattractiveness of the media used so far, turning with the enthusiasm of students in taking lessons due to the limited time for face-to-face online classes. While online, students are only given a YouTube video link as a review of the subject matter. Interviews with students or students showed problems in applying less creative methods, namely by reading the worksheets and listening to the teacher's lectures which resulted in boredom in attending fiqh lessons.

Research data were collected using validation sheets of material experts, linguists, and media experts and then analyzed using a Likert scale. In this study, researchers are more likely to use a pattern of proving the validity of which conclusions are drawn from the validation results. For example, the validation of fiqh learning media using the iSpring Suite on Friday prayer material was examined by three experts, consisting of material experts, linguists, and media experts. After being validated by all experts, the researcher revised the improvement for the learning media. 


\section{Material Expert Validation}

The results of the validation assessment by material experts on learning media are described in the form of percentages.

Table 1. The results of the material expert validation assessment

\begin{tabular}{|c|c|c|}
\hline No & Aspect & Percentage \\
\hline 1 & Learning & $80,36 \%$ \\
\hline 2 & Material substance & $87,50 \%$ \\
\hline & Average & $83,93 \%$ \\
\hline
\end{tabular}

Table no. 1 contains the results of the validation assessment by material experts, which in this case is carried out by $\mathrm{KH}$ Abdul Wahab Hasbullah University lecturers, Mrs Emi Lilawati M.Pd, got a percentage value of $87.50 \%$. The average assessment of the material expert validator gets $83.93 \%$, with a very decent category. The validation aspect of the material expert includes two things, namely $80.36 \%$ learning and $87.50 \%$ material substance.

The learning details are clarity of objectives by $100 \%$, the relevance of objectives by $80 \%$, coverage and depth by $60 \%$, the accuracy of use by $40 \%$, and interactive by $20 \%$.

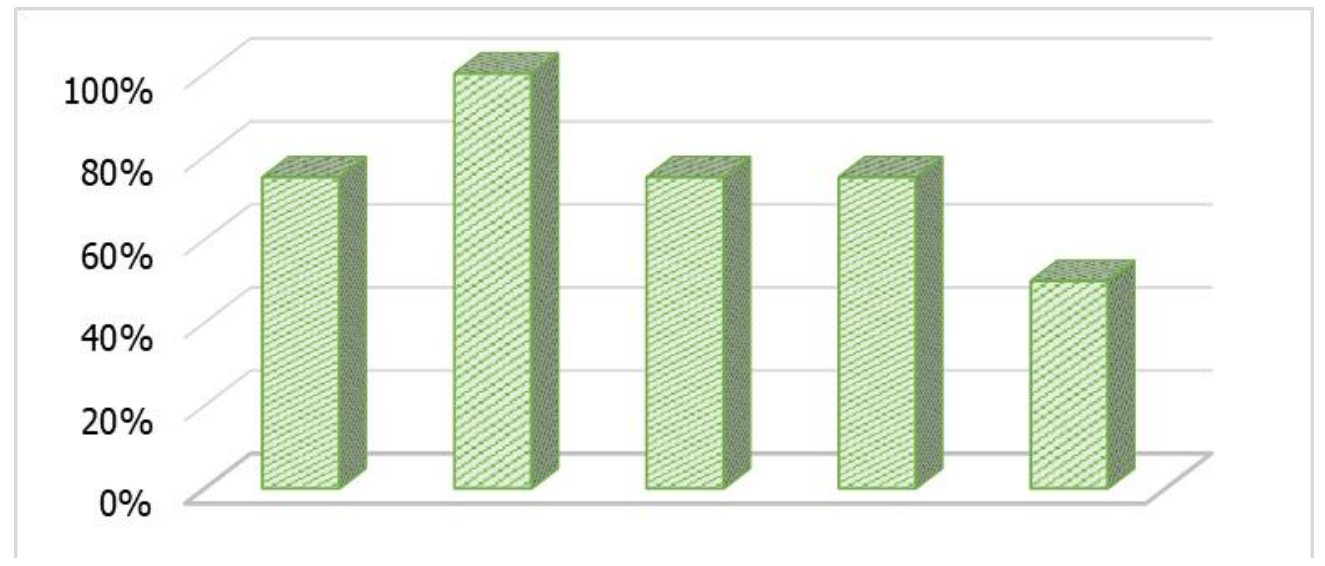

Figure 1. Learning Aspects (1-5)

The material's details are $100 \%$ clarity, $100 \%$ evaluation consistency, $80 \%$ relevance, $80 \%$ feedback, and $80 \%$ systematics.

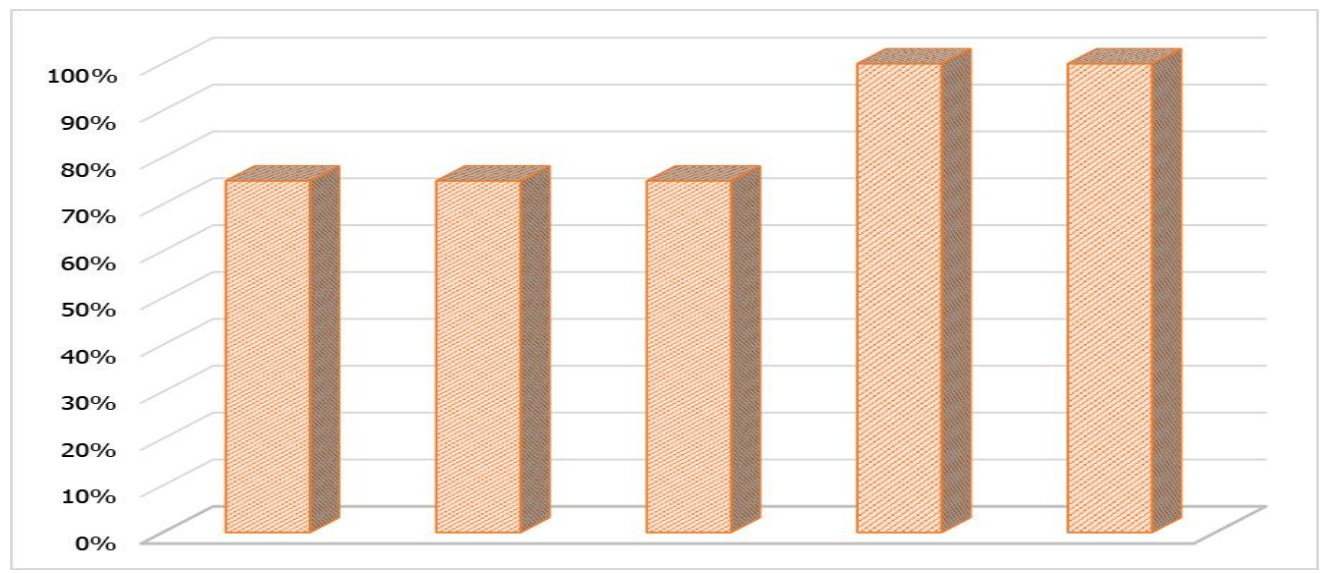

Figure 2. Aspects of Material Substitution (1-5) 
The next plan for the substance of the material is the actuality of $100 \%$, the depth of the material by $80 \%$, the accuracy of use by $80 \%$, the truth of the material by $100 \%$.

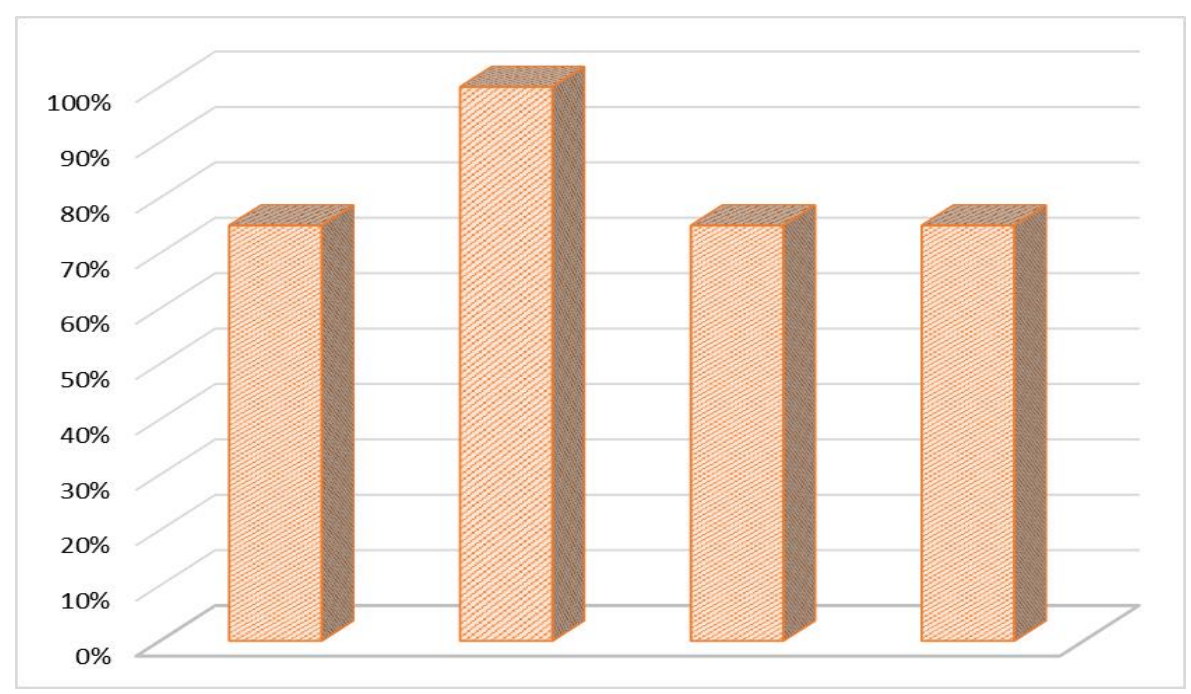

Figure 3. material substance (6-10)

\section{Linguist Validation}

Validation by linguists, which in this case was carried out by a lecturer at KH. Abdul Wahab Hasbullah University, Mr. M. Dzikrul Hakim Al-Ghozali, S.Pd.I, M.Pd.I. The average score of the linguist validators is $81.25 \%$.

Table 2. linguist validation assessment results

\begin{tabular}{|c|l|c|}
\hline No & \multicolumn{1}{|c|}{ Aspect } & Percentage \\
\hline 1. & Clear instructions for use & $50 \%$ \\
\hline 2. & Accuracy of terms & $75 \%$ \\
\hline 3. & Ease of understanding the flow of material & $100 \%$ \\
\hline 4. & Unity of language use & $100 \%$ \\
\hline $\mathbf{5 .}$ & Accuracy of dialogue/discourse text & $75 \%$ \\
\hline $\mathbf{6 .}$ & The suitability of language with students' thinking level & $75 \%$ \\
\hline 7. & Ability to encourage curiosity & $100 \%$ \\
\hline $\mathbf{8 .}$ & Use of EYD & $75 \%$ \\
\hline & Average & $81,25 \%$ \\
\hline
\end{tabular}




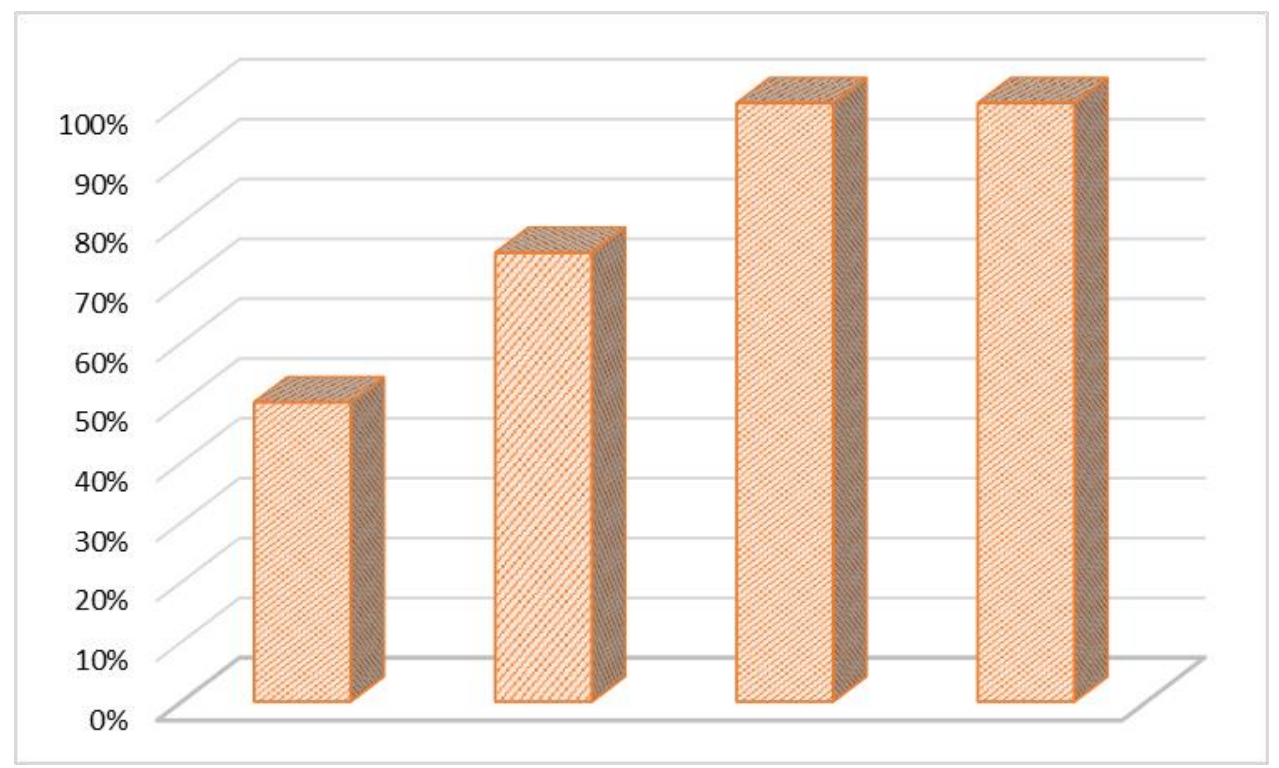

Figure 4. validation of linguists (1-4)

The linguist's validation images include clarity of usage instructions by $50 \%$, the accuracy of terms by $75 \%$, ease of understanding the material by $100 \%$, and unity of language use by $100 \%$.

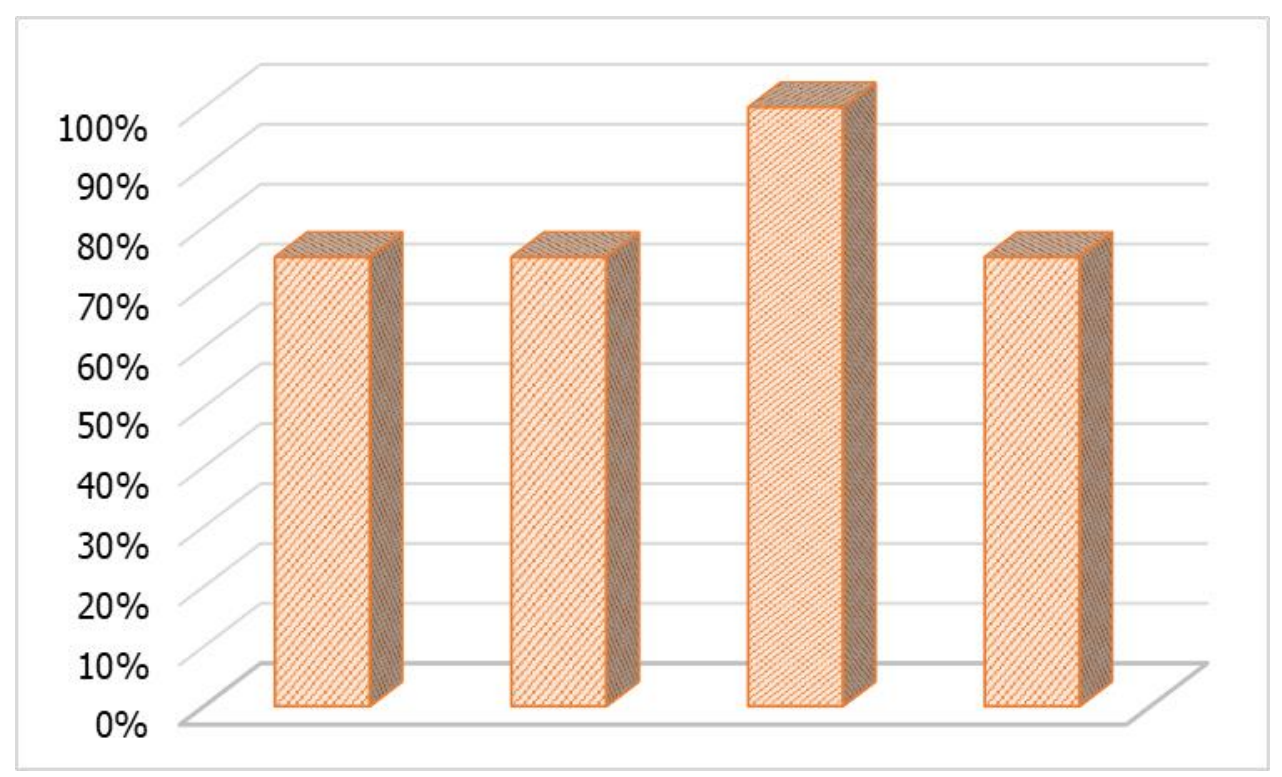

Figure 5. validation of linguists (5-8)

The details of the linguist validation images include the accuracy of dialogue/discourse text by $75 \%$, the suitability of language with students' thinking level by $75 \%$, the ability to encourage curiosity by $100 \%$, and the use of EYD by $75 \%$.

\section{Media Expert Validation}

Mr Moh carried out the validation assessment by media experts in this case. Anshori Aris Widya, M. Kom. consists of two aspects: general aspects and device engineering or media design. The average value of both parts is $75 \%$. 
Table 3. Assessment of media expert validation

\begin{tabular}{|c|c|c|}
\hline No & Aspect & Percentage \\
\hline 1. & General aspects & $75 \%$ \\
\hline 2. & $\begin{array}{c}\text { aspects of device engineering or } \\
\text { media design } \\
\text { Average }\end{array}$ & $66,25 \%$ \\
\hline & A & $70,63 \%$ \\
\hline
\end{tabular}

General aspects include creative and innovative by $70 \%$, communicative by $70 \%$, and only elements by $70 \%$.

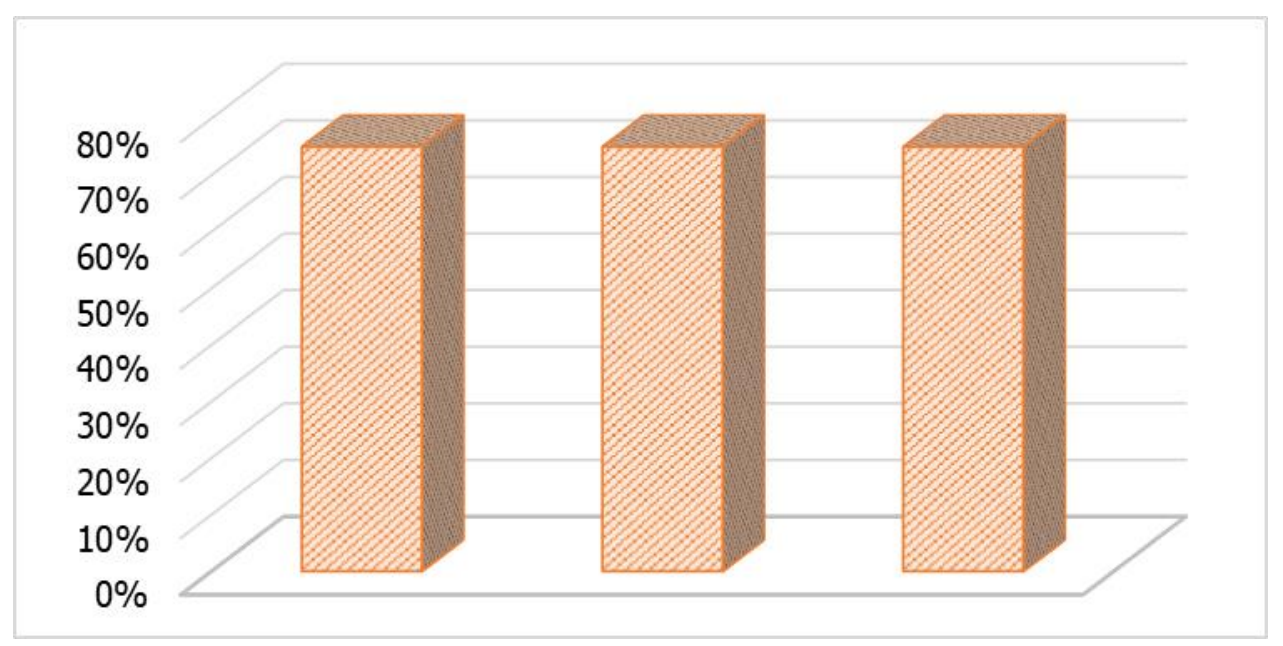

Figure 6. General aspects (1-3)

Meanwhile, device engineering or media design aspects include $70 \%$ effectiveness and efficiency, $70 \%$ reliability, $70 \%$ maintainability, $70 \%$ usability, and $70 \%$ accuracy.

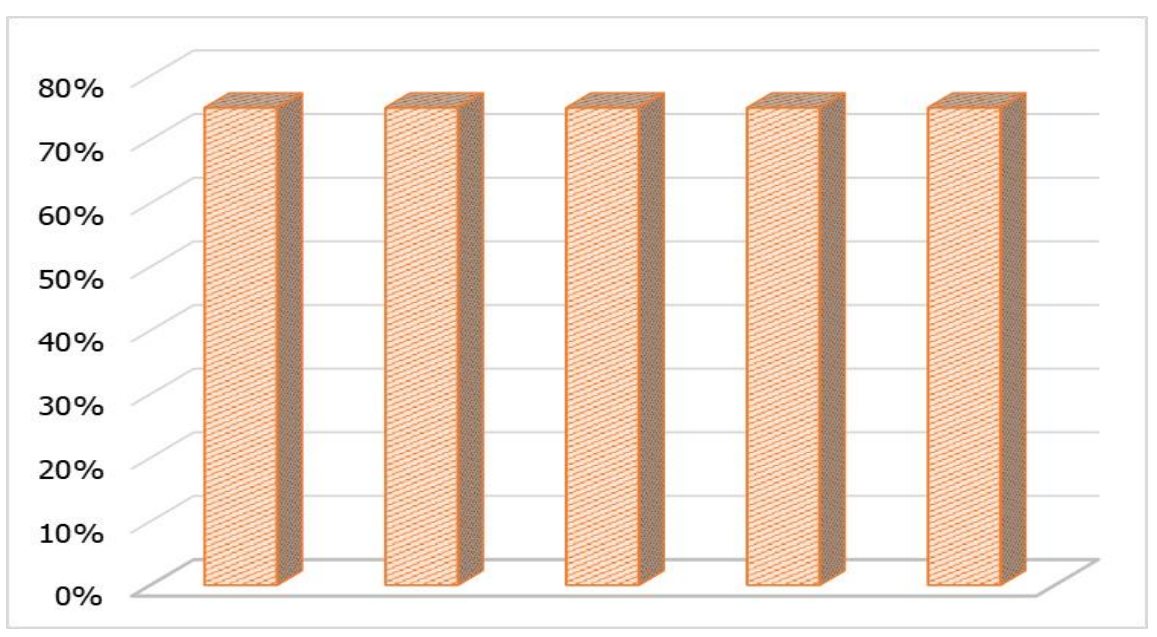

Figure 7. engineering aspects (4-8)

\section{CONCLUSION}

Based on the previous description, it can be concluded that the development of learning media on fiqh subjects at MTSN 14 MEGALUH is feasible to use. This is done by considering the quality of the design and the suitability of the display with the psychological development of students, adjusting the content of the material with references so that the material packaged in the learning media becomes effective and 
easy to understand. As for the feasibility and effectiveness of this learning media, it has received outstanding recognition. It can be proven by the results of the average calculation and analysis of the influence of learning media that get a fantastic response from students.

\section{ACKNOWLEDGEMENTS}

With complete gratitude for the presence of Allah SWT, and without losing deep respect, the researcher would like to thank those who have helped the researcher in completing the writing of the journal with the title "the feasibility of iSpring Suite learning media with the use of android in fiqh subjects". Especially I would like to thank my parents, who have supported and prayed for this writing. Secondly, I would like to thank Ms Siti Sulaikho, M.Pd as the supervisor in this writing, and lastly, I would like to thank my friends who have provided support and support. Both moral and material assistance.

\section{REFERENCES}

[1] Amarulloh, R., Y. \& I. (2013). Kelayakan Teoritis Media Pembelajaran Multimedia Intratif Materi Mutasi Untuk SMA. Jurnal Bioedu, 2(2), 134-136.

[2] Arsyad, A. (2020). media pembelajaran.

[3] Eva, R., \& Siagian, F. (2012). PENGARUH MINAT DAN KEBIASAAN BELAJAR SISWA. Jurnal Formatif, 2(2), 122-131.

[4] Evi Damayanti. (2018). Efektivitas Penggunaan Media Ispring Suite 8 Terhadap Hasil Belajar Sejarah Kelas X Sma Negeri 5 Pontianak. Journal of Chemical Information and Modeling, 53(9), 1689-1699.

[5] Hanafi, I. (2017). ORIENTASI FIKIH DALAM PENDIDIKAN ISLAM Imam Hanafi. Al-Fikra: Jurnal Ilmiah Keislaman, 11(1), 16. https://doi.org/10.24014/af.v11i1.3850

[6] Hidayati, N., \& Hakim, L. (2012). Fakultas Ekonomi , Unesa , Kampus Ketintang Surabaya. Jurnal Akuntansi AKUNESA, 1-11.

[7] Himah, F. (2017). Pengembangan Multi Media Interaktif Menggunakan Ispring Suite 8 Pada Sub Materi Zat Aditif Untuk Meningkatkan Hasil Belajar Siswa SMP Kelas VIII. Jurnal Unesa, 5(2), 73-82.

[8] Huda, K., Sakti, hadi gunawan, \& Ary, P. (2019). pengaruh media ispring suite 9 terhadap hasil belajar siswa kelas X ipa mata pelajaran biologi di ma darul muhajirin praya. (3), 216-223.

[9] Ikhwan, A., Anwar, S., \& Mahmudah, N. (2021). Tahsin and Tahfidz Learning System at Integrated Islamic Elementary School (SDIT) Insan Madani During the Pandemic Covid-19. Al-Hayat: Journal of Islamic Education (AJIE), 5(1), 1-11.

[10] Izzati, F. D., \& Sumarsih. (2017). Pengembangan Media Pembelajaran Aplikasi Peta Akuntansi ( TAKSI ) Berbasis Android Pada Materi Siklus Akuntansi Perusahaan Jasa Development of Learning Media Using Android-Based Application Peta Akuntansi ( Taksi ) on Accounting Cycle of Service Enterpris. Jurnal Pendidikan Akuntansi Indonesia, XV(2), 32-46. 
[11] Juwansyah, A. (2015). Pembangunan Aplikasi Child Tracker Berbasis Assisted Global Positioning Sytem ( A-GPS ) Dengan Plalatform Android. Jurnal Ilmiah Komputer Dan Informatika, 1(1), 1-8.

[12] Kuswanto, J. \& Radiansyah, F. (2018). Media Pembelajaran Berbasis Android Pada Mata Pelajaran Sistem Operasi Jaringan Kelas XI. Jurnal Media Info Tama, 14(1), $15-20$

[13] Mansir. F \& Karim. A. (2020). Urgensi pembelajaran fiqih dalam meningkatkan religiusitas siswa madrasah. Jurnal of Islamic Education Studies, 5(2), 168-179.

[14] Martiningsih, R. (2018). Peningkatan Hasil Belajar Himpunan Dengan Menggunakan Aplikasi Ispring Suite 8. Jurnal Teknodik, 22(1), 1-13.

[15] Muhson, A. (2010). Pengembangan Media Pembelajaran Berbasis Teknologi Informasi. Jurnal Akuntansi Indonesia, VIII(2), 1-10.

[16] Saputro, B. (2017). Manajem Penilitian Pengembangan.

[17] Sasahan, E. Y., Oktova, R., \& I.R.N., O. O. (2017). Pengembangan Media Pembelajaran Interaktif tentang Optika Berbasis Android Menggunakan Perangkat Lunak Ispring Suite 7.0 untuk Mahasiswa S-1 Pendidikan Fisika pada Pokok Bahasan Interferensi Cahaya. Prosiding SNFA (Seminar Nasional Fisika Dan Aplikasinya), 2, 52. https://doi.org/10.20961/prosidingsnfa.v2i0.16364

[18] Sukiman. (2012). Pengembangan Media pembelajaran.

[19] Sutiasih, aminda dwi, \& Saputri, renny permata. (2019). Pengembangan mobile learning berbasis android sebagai media pembelajaran ekonomi. Jurnal Pendidikan Ekonomi, 6(2), 137-147.

[20] zainati, husniyatus salamah. (2017). pengembangan media pembelajaran berbasis ict.

[21]Zukhrufin, F. K., Anwar, S., \& Sidiq, U. (2021). Desain Pembelajaran Akhlak Melalui Mata Pelajaran Pendidikan Agama Islam. JIE: Journal of Islamic Edication, 6(2). 